\title{
0 papel da Escola para o enfrentamento da Violência Sexual contra crianças nos discursos de professores do Ensino Fundamental em Augusto Corrêa - PA
}

\author{
Wellen Renata Costa Santos* \\ Raquel Atmorim dos Santos** \\ goana d'Atre de Vasconcelos Weves*** \\ Marcelo do Vale Eliveira****
}

* Graduanda em Pedagogia. Bolsista do Núcleo de Estudos e Pesquisas sobre Educação, Currículo, Formação de Professores e Relações Étnico-Raciais, e-mail: maiara.silva75@yahoo.com.br.

${ }^{* *}$ Doutora em Educação pela Universidade Federal do Pará (UFPA). Mestra em Educação (UFPA). Professora Adjunta da UFPA, Campus Universitário de Bragança, Faculdade de Educação. Professora do Programa de Pós-Graduação em Linguagens e Saberes na Amazônia (PPLSA). Pesquisadora do Núcleo de Estudos e Pesquisa sobre Formação de Professores e Relações Étnico-Raciais (GERA/UFPA). Diretora das Áreas Acadêmicas da Associação Brasileira de Pesquisadores Negros ABPN (2017-2018). Graduada em Pedagogia pela Universidade da Amazônia (UNAMA). E-mail: rakelamorim@yahoo.com.br

${ }^{* * *}$ Doutora em Educação pela Universidade Federal do Pará (UFPA). Mestra em Educação (UFPA). Professora Adjunta da Universidade Federal do Pará, Faculdade de Educação, Campus Universitário de Bragança e Professora do Programa de Pós-Graduação em Linguagens e Saberes na Amazônia. Vice Coordenadora do Grupo de Estudo e Pesquisa em Educação de Jovens e Adultos e Diversidade na Amazônia. Pesquisadora participante do Grupo de Estudo e Pesquisa da Educação do Campo (GEPERUAZ) e Grupo de Pesquisa sobre a Juventude e Representações Sociais da Educação (GEPEJURSE). Pesquisadora da Cátedra Paulo Freire. Integrante do Movimento de Educação de Jovens e adultos na Amazônia paraense.

${ }^{* * * *}$ Doutor em Sociologia pelo Programa de Pós-graduação em Sociologia e Antropologia, do Instituto de Filosofia e Ciências Humanas, da Universidade Federal do Pará (PPGSA/IFCH/UFPA, 2018). Mestre em Ecologia de Ecossistemas Costeiros e Estuarinos pelo Programa de Pós-graduação em Biologia Ambiental, do Instituto de Estudos Costeiros (PPGBA/IECOS/UFPA). Graduado com Bacharelado e Licenciatura Plena em Ciências Sociais pela Faculdade de Ciências Sociais, do Instituto de Filosofia e Ciências Humanas, da Universidade Federal do Pará (FACS/IFCH/UFPA). Atua como Técnico em

@rquivo Brasileiro de Educação, Belo Horizonte, v. 6, n. 14, mai-ago, 2018. 


\section{RESUMO}

O presente estudo objetivou analisar os discursos de professores sobre 0 papel da escola para 0 enfrentamento da violência sexual contra crianças no Ensino Fundamental no município de Augusto Corrêa-PA, Nordeste do Pará. A metodologia de pesquisa foi pautada na abordagem qualitativa. A técnica de coleta de dados foi $O$ questionário com perguntas semiestruturadas. A amostragem foi constituída por 04 (quatro) professores de uma Escola Municipal de Augusto Corrêa-PA. A análise ocorreu pela organização e tabulação, seguida análise e interpretação dos discursos, com transcrição total ou parcialmente dos discursos mais expressivos. Os discursos dos professores demonstram a compreensão sobre a violência sexual, mas o desconhecimento sobre a Rede de Proteção dos direitos da criança e adolescentes. Neste sentido, eles apresentam em seus argumentos, que o papel da escola limita-se a conscientização, sem apresentar uma ação de protagonista no sentido do atendimento das crianças que já tiveram seus direitos violados. Tais discursos reafirmam a necessidade de formação inicial e continuada que possibilite um conhecimento acerca dos direitos humanos, sobretudo, medidas e ações efetivas para o enfrentamento da violência sexual na escola.

Palavras-Chave: Violência Sexual. Discurso do professor. Papel da Escola.

\section{ABSTRACT}

The present study aimed to analyze the discourses about the school's role in confronting sexual violence against children in elementary school in the city of Augusto Corrêa-PA, Northeast of Pará. The research methodology was a qualitative approach. The data collection technique was launched in the semistructured. The sample was built by 04 teachers of the Augusto Corrêa-PA

Assuntos Educacionais da Universidade Federal do Pará, lotado no Campus Universitário de Bragança.

@rquivo Brasileiro de Educação, Belo Horizonte, v. 6, n. 14, mai-ago, 2018. 
Municipal School. An analysis was made by the organization and documentation of the periodicals, followed by the analysis and interpretation of the speeches, with the total or partial transcription of the most expressive speeches. The teachers' discourses demonstrate an understanding about sexual violence and ignorance about the Rights of the Child and Adolescents Network, in this sense, they present themselves in their objectives, the role of the school is limited to awareness, without presenting an action. Of protagonist in the sense of care of children who already have their rights violated. Such discourses are focused on the initial and continuous learning that allow the knowledge about human rights, above all, and actions to confront sexual violence in school.

Keywords: Sexual Violence. Teacher's speech. Role of the School.

\section{INTRODUÇÃO}

A violência sexual é compreendida como a violação dos direitos sexuais, no sentido de abusar ou explorar do corpo e da sexualidade de crianças e adolescentes. Ela pode ser classificada em abuso sexual (extra ou intrafamiliar') ou exploração sexual² (LAVAREDA; MAGALHÃES, 2015). A maioria dos casos de abuso sexual é cometida por pessoas sem patologia alguma e se deve à cultura ainda permissiva quanto às práticas violentas e sexuais com crianças e adolescentes (LAVAREDA; MAGALHÃES, 2015).

O tema "Violência sexual contra crianças" surgiu a partir de algumas inquietações sobre o olhar da escola em relação às crianças

\footnotetext{
${ }^{1}$ De acordo com Lavareda e Magalhães (2015) o abuso extrafamiliar se refere aos casos em que o autor não tem vínculo de pertencimento familiar, e o intrafamiliar é o praticado por autores que são responsáveis ou familiares da vítima.

${ }^{2}$ É o uso sexual de criança ou adolescente para obter lucro, troca ou vantagem. Se expressa de quatro formas: prostituição, pornografia, tráfico e turismo sexual. Trata-se de um fenômeno mundial, que atinge em especial o sexo feminino, mas não apenas (Lavareda e Magalhães, 2015).
}

@rquivo Brasileiro de Educação, Belo Horizonte, v. 6, n. 14, mai-ago, 2018. 
que são vítimas de violência sexual, bem como as atitudes que os professores tendem a tomar caso estejam em contato com uma vítima. Além disso, a escuta de pessoas que foram vítima de abuso sexual durante a infância relatando que a escola não apresentava nenhuma ação de enfrentamento.

As memórias de infâncias marcadas pelo sofrimento psíquico reflexo da violência sexual intrafamiliar, revelam igualmente percepções de mudanças de comportamento, isolamento, insônia, medo excessivo, tristeza, que atravessam a adolescência e de escolas omissas que invisibilizam estes sujeitos e esta realidade.

Ao longo dos anos, a sociedade vem passando por um intenso processo de transformação em todas as esferas, mudanças econômicas, políticas e sociais, porém quando se trata de violência sexual contra crianças e adolescentes se torna um acontecimento sem muitas mudanças, pois este é, por vezes, um tabu, mesmo havendo avanços quando se trata dos direitos das crianças. Muitas crianças e adolescentes ainda passam por isso todos os dias, a cada momento vem aumentado o índice desse tipo de violência. Esse problema envolve também a família, que, muitas vezes, não consegue perceber o que se passa com a criança e na maioria das vezes essa violência ocorre dentro do ambiente familiar (COSTA; JUNQUEIRA; MENESES, 2013; LIMA; ALBERTO, 2015).

Para Romero (2007, p. 19) a "[...] pior forma de violência é aquela sofrida dentro da própria casa, diretamente dos pais, parentes responsáveis ou pessoas conhecidas [...]". Para ela, o abuso ocorre de modo sigiloso e atinge dimensões complexas, que vai desde traumas até doenças sexualmente transmissíveis e gravidez. Essa criança tem um vínculo afetivo com o abusador, havendo uma confiança que é quebrada, vindo então o medo de voltar a acontecer, pois haverá o

@rquivo Brasileiro de Educação, Belo Horizonte, v. 6, n. 14, mai-ago, 2018. 
convívio com o agressor, deixando a criança sem coragem de falar ou até mesmo com vergonha de se expor.

A escola ocupa um papel fundamental, pois a criança passa uma boa parte do seu dia nesse ambiente; os professores podem assim interagir e observar, mas muitas vezes, não se encontram preparados para identificar tais casos, daí a importância da formação continuada de professores para o trato com as questões que envolvem a violência sexual contra crianças e adolescentes. A escola e seus agentes não podem separar-se dos debates sobre questões como direitos humanos, proteção a crianças e adolescentes, entre outros temas que, muitas vezes, afetam a vida de crianças e adolescentes na escola. É necessário, portanto que esta esteja sempre em formação para saber que medidas tomar após descobrir o ato e oferecer suporte à vítima e, se preciso, à própria família.

Para Brino e Williams (2003, p.115) "[...] O principal agressor sexual encontra-se na família, a escola mostra-se como local ideal para detecção e intervenção junto a tais casos". Esse tipo de ato é um problema muito sério, e dificilmente deixa marcas físicas, porém, deixa consequências graves para 0 desenvolvimento da vítima, tanto psicológicas quanto sociais. A literatura corrobora que "[...] crianças ou adolescentes podem desenvolver quadros de depressão, transtornos de ansiedade, alimentares, dissociativos, hiperatividade, déficit de atenção e transtorno de personalidade [...]" (AVEZEDO HABIGZANG; KOLLER; MACHADO, 2005, p.342).

Dessa maneira, as mudanças no comportamento da criança podem ser avaliadas, mas não de maneira isolada, sendo que, na maioria dos casos, ela não consegue relatar o abuso, ocasionando assim, a síndrome do segredo.

Nesse sentido, Balbinolti (2009, p.7) assegura:

@rquivo Brasileiro de Educação, Belo Horizonte, v. 6, n. 14, mai-ago, 2018. 
Uma das piores consequências que levam a síndrome do segredo é o prosseguimento do convívio com o agressor e a reincidência do abuso. A imposição do silêncio se dá sob ameaça de ser a criança responsabilizada pelo termino do casamento dos pais, desintegração familiar, prisão do abusador, expulsão da criança do lar, sua morte ou mesmo do próprio descredito da palavra do menor. Mentem sobre a ameaça de castigo, pois é imposto que o ocorrido é um segredo entre ela e o agressor.

Compreender o papel da escola mediante a esses problemas torna-se essencial para rever e avaliar quais medidas estão sendo tomadas diante desses casos de abusos, sendo a escola uma intermediária dos conflitos existentes dentro da sociedade, pois a "[...] escola tem também a função de atendimento, ou seja, de proteger seus estudantes, crianças e adolescentes contra qualquer violação de seus direitos" (BRASIL, 2008, p.86). A escola, sozinha, não é capaz de mudar tudo, todavia, ocupa um lugar muito importante diante deste problema, podendo ser ela a ajuda que a criança tanto espera, mas não consegue buscar sozinha.

O debate sobre violência sexual na escola é basilar, pois tem papel importante podendo contribuir como agente de proteção para evitar a exclusão e o preconceito, bem como atuar na prevenção e criação de espaços pedagógicos que possibilitem a ampliação da discussão acerca de temas como a sexualidade, respeito, entre outros.

É importante considerar que os abusadores são pessoas comuns, que vivem no mesmo espaço da criança abusada; mesmo que não deixe marcas físicas, esse tipo de ato deixa consequências graves no psicológico, sendo diferentes umas das outras variando de acordo com a idade daquele que é abusado e do nível do abuso.

Para Faleiros e Faleiros (2008) a escola, portanto, é muito mais que conteúdos, não podendo se tornar apenas local de trabalho, mas

@rquivo Brasileiro de Educação, Belo Horizonte, v. 6, n. 14, mai-ago, 2018. 
também um local de vida, contribuindo para o desenvolvimento da criança tanto física, social e psicológica, tendo que oferecer proteção e amor. Nesse sentido, Paiva (2015, p.19) corrobora:

Educar é um processo para o desenvolvimento integral com um propósito amplo na formação da criança, atendendo a suas especificidades de desenvolvimento emocional, social, como também às necessidades de cuidado com a saúde, com o bem-estar, entre outros.

Borges (2007) ressalta que a violência sexual traz sérias consequências para a vítima, podendo ser severas e diversas, pois tem efeitos tanto fisicamente, como traumas físicos (gravidez, aborto e doenças sexualmente transmissíveis) quanto emocionais (distúrbios na sexualidade, maior vulnerabilidade para desenvolver problemas psíquicos como depressão, medo, ansiedade e tentativas de suicídio).

Martins (2007, p. 27) assegura que "[...] o abuso sexual de crianças e adolescentes são um dos tipos de violência mais frequentes e assume muitas formas que vão, desde o acariciamento até o estupro [...]", ou seja, qualquer contato, podendo incluir toques, carícias, sexo oral, assédio, entre outros, podendo, também, ter ou não o uso da força física. A violência sexual, portanto, é uma das maneiras mais cruéis de maus-tratos, sendo inaceitável por Lei qualquer ato de violência contra crianças.

O Estatuto da Criança e Adolescente (ECA), em seu artigo $5^{\circ}$ estabelece que nenhuma criança será objeto de qualquer forma de negligência, discriminação, exploração, violência, crueldade e opressão punida na forma de lei qualquer atentado, por ação ou omissão, aos seus direitos fundamentais.

A violência sexual contra crianças traz consequências e marcas físicas, psicológicas e sociais deixadas ao longo do tempo na criança vítima de abuso sexual e que, muitas vezes, não são percebidas pela 
escola e seus agentes. A ausência dessa discussão nos espaços escolares, nas universidades e nos cursos de formação de professores, bem como as interpretações errôneas a respeito dessa temática e a desconstrução de paradigmas arraigados em nossos imaginários de família, maternidade, paternidade, sexualidade, entre outros, contribui para silenciar, invisibilizar esse problema nos diferentes espaços sociais, inclusive na escola.

Diante da situação apresentada, nos inquietamos e questionamos: Quais os discursos de professores sobre o papel da escola para o enfrentamento da violência sexual contra crianças no Ensino Fundamental em Augusto Corrêa-PA?

O estudo apresenta como objetivo geral analisar os discursos de professores sobre o papel da escola para o enfrentamento da violência sexual contra crianças no Ensino Fundamental em Augusto Corrêa-PA. E como objetivos específicos:

a) investigar a escola e o enfrentamento a violência sexual contra crianças no contexto escolar brasileiro;

b) identificar, nos discursos de professores, o papel da escola para o enfrentamento da violência sexual contra crianças no Ensino Fundamental em Augusto Corrêa-PA.

\section{PROCEDIMENTO METODOLÓGICO}

\section{1 Área de estudo}

O estudo em questão ocorreu no estado do Pará, especificamente no município de Augusto Corrêa, no nordeste paraense. O município de Augusto Corrêa pertence à Mesorregião do

@rquivo Brasileiro de Educação, Belo Horizonte, v. 6, n. 14, mai-ago, 2018. 
Nordeste Paraense e à Microrregião Bragantina (Figura I). A sede municipal tem as seguintes coordenadas geográficas: 010 01' 45" de latitude Sul e 460 38' 57" de longitude a Oeste de Greenwich, os habitantes chamam-se de Augusto correenses. A seguir a mapa com a localização de Augusto Corrêa-PA.

\subsection{Coleta de dados}

Para a realização da coleta de dados, inicialmente, entrou-se em contato com a escola pesquisada e seus respectivos professores, agendando o encontro presencial para a aplicação do instrumento questionário.

No presente estudo, se optou pela pesquisa de abordagem qualitativa, que na concepção de Godoy (1995) ocupa um lugar de destaque, pois estuda os fenômenos que estão envolvendo os seres humanos. Assim, durante o trabalho de pesquisa o pesquisador vai a campo para capturar o elemento que estuda a partir do olhar dos sujeitos envolvidos.

Minayo (1994) ressalta que a pesquisa qualitativa responde a questões muito particulares. Ela se preocupa, nas ciências sociais, com um nível de realidade que não pode ser quantificado. Ou seja, ela trabalha com o universo de significados, motivos, aspirações, valores e atitudes, o que correspondem um espaço mais profundo das relações, dos processos e dos fenômenos que não podem ser reduzidos à operacionalização de variáveis.

Os dados foram coletados a partir de um questionário, este instrumento segundo Severino (2007, p.125) é considerado como "[...] o conjunto de questões, sistematicamente articuladas, que se destinam a levantar informações escritas por parte dos sujeitos pesquisados, com

@rquivo Brasileiro de Educação, Belo Horizonte, v. 6, n. 14, mai-ago, 2018. 
vista a conhecer a opinião dos mesmos sobre os assuntos em estudo".

O questionário foi constituído de 12 (doze) questões, previamente elaboradas que contribuíram para traçar o perfil identitário e profissional dos professores da respectiva escola, assim como captar seus discursos a respeito do papel da escola para o enfrentamento da violência sexual contra crianças no Ensino Fundamental.

\subsection{Amostragem}

A amostragem foi realizada em uma Escola Municipal de Augusto Corrêa-PA ${ }^{3}$, situada na comunidade campesina de Santa Maria do Açaizal' ${ }^{4}, \mathrm{n}=01$ (Escola Municipal de Ensino Fundamental Paulino Alves Corrêa). O critério da escolha dessa escola foi ter professores que possuem alunos no Ensino Fundamental que sofreram violência sexual, e que participaram regularmente da escola no ano letivo de 2017.

A escola atende cerca de 500 alunos distribuídos na Educação Infantil (Pré-escolar), Ensino Fundamental ( $1^{\circ}$ ao $9^{\circ}$ ano), Educação de Jovens e Adultos ( $3^{a}$ e $4^{a}$ Etapa) e, ainda atua no Programa Mais Educação (turnos matutino, vespertino e noturno). Os alunos são de baixa renda, a maioria são filhos de agricultores que possuem baixa escolaridade e a maior parte do ano sobrevive da venda da farinha que oscila muito de acordo com a demanda da produção.

A estrutura física da escola é composta por 07 (sete) salas de aula, sendo que esses espaços estão divididos em outros anexos na Vila de Santa Maria do Açaizal (por conta do espaço pequeno da escola),

\footnotetext{
${ }^{3}$ O município de Augusto Corrêa está localizado na Mesorregião Nordeste do Estado do Pará e integra a Microrregião Bragantina com os seguintes municípios: Bonito, Bragança, Capanema, Igarapé-Açu, Nova Timboteua, Peixe-Boi, Primavera, Quatipuru, Santa Maria do Pará, Santarém Novo, Tracuateua e São Francisco do Pará (IBGE, Sinopse do Censo Demográfico, 2010).

${ }^{44}$ A vila de Santa Maria de Açaizal faz parte de uma divisão entre Viseu e Augusto Correa, meio de subsistência é a agricultura, sobrevive a maior parte do ano da venda da farinha que oscila muito de acordo com a demanda da produção
}

@rquivo Brasileiro de Educação, Belo Horizonte, v. 6, n. 14, mai-ago, 2018. 
01 (uma) secretaria, 01 (uma) diretoria, 01 (uma) cozinha e 04 (quatro) banheiros. O corpo funcional da escola é composto por 01 (uma) diretora, 20 (vinte) professores, 02 (dois) coordenadores, 01 (uma) secretária, 03 (três) auxiliares de secretaria, 08 (oito) auxiliares de serviços gerais, 02 (dois) vigias e 02 (dois) porteiros. Desses foram selecionados 04 (quatro) docentes que atuam no Ensino Fundamental.

Os critérios para a seleção dos sujeitos foram professores que tinham em suas turmas alunos que sofreram violência sexual na família e estavam na escola de Ensino Fundamental. Essa escolha foi realizada por meio de conversa agendada com os professores, anterior a aplicação dos questionários, além da disponibilidade dos docentes em respondê-los. Segundo Pádua (2007, p. 67) "[...] a amostra é a representação menor de um todo maior, a fim de que o pesquisador possa analisar um dado universo".

Para preservar a identidade dos professores, optamos por identificá-los por letra do alfabeto, seguido pela identificação do sexo, idade, tempo de trabalho, autoclassificação racial e formação, conforme apresentado abaixo.

\section{Quadro 1 - Perfil identitário e profissional dos sujeitos da pesquisa}

\begin{tabular}{|c|c|c|c|c|c|}
\hline $\begin{array}{c}\text { SUJEITOS } \\
\text { DA } \\
\text { PESQUISA }\end{array}$ & SEXO & IDADE & $\begin{array}{l}\text { TEMPO DE } \\
\text { TRABALHO }\end{array}$ & $\begin{array}{c}\text { AUTOCLASSIFICAÇÃO } \\
\text { RACIAL }\end{array}$ & FORMAÇÃO \\
\hline Professor A & Masculino & $\begin{array}{l}\text { Mais de } \\
46 \text { anos }\end{array}$ & $\begin{array}{c}\text { De } 5 \text { a } 10 \\
\text { anos }\end{array}$ & Pardo & $\begin{array}{l}\text { Magistério- } \\
\text { Nível Médio }\end{array}$ \\
\hline $\begin{array}{c}\text { Professora } \\
\text { B }\end{array}$ & Feminino & $\begin{array}{l}\text { De } 26 \text { a } \\
30 \text { anos }\end{array}$ & $\begin{array}{c}\text { Menos de } 5 \\
\text { anos }\end{array}$ & Pardo & Pedagogia \\
\hline $\begin{array}{l}\text { Professora } \\
\text { C }\end{array}$ & Feminino & $\begin{array}{l}\text { De } 26 \text { a } \\
30 \text { anos }\end{array}$ & $\begin{array}{l}\text { De } 5 \text { a } 10 \\
\text { anos }\end{array}$ & Pardo & $\begin{array}{c}\text { Pedagogia com } \\
\text { Especialização } \\
\text { em Gestão } \\
\text { Escolar e } \\
\text { Educação } \\
\text { Infantil }\end{array}$ \\
\hline $\begin{array}{c}\text { Professora } \\
\text { D }\end{array}$ & Feminino & $\begin{array}{l}\text { De } 41 \text { a } \\
45 \text { anos }\end{array}$ & $\begin{array}{l}\text { Mais de } 15 \\
\text { anos }\end{array}$ & Pardo & Pedagogia \\
\hline
\end{tabular}

Fonte: Elaborado pela autora com base em dados da pesquisa.

@rquivo Brasileiro de Educação, Belo Horizonte, v. 6, n. 14, mai-ago, 2018. 
As professoras, com idade que varia entre 26 a 30 anos, 41 a 45 anos e somente um do sexo masculino com mais de 46 anos. A maioria possui pouco tempo de trabalho que corresponde a menos de 5 anos e de 5 a 10 anos e somente uma professora tem experiência a mais de 15 anos.

Quanto à autoclassificação racial, os professores se identificam como pardos. Para Botelho e Schwarcz (2012) o termo pardo forma uma categoria que contém os mais escuros. Nesse status social, não é preto, nem branco, já que na prática se aproxima na representação popular dos negros. Para ela, estamos, portanto, diante de uma categoria interna, oficializada pelo costume e dificilmente compreensivel para aqueles que conhecem 0 país apenas de passagem. A autoclassificação foi fundamental para compreendermos a identificação racial de professores e sua relação com crianças que, na sua maioria, são negras (pretas e pardas), conforme relatos das professoras.

As professoras na sua maioria possuem Licenciatura Plena em Pedagogia, sendo que somente uma professora possui Especialização em Gestão Escolar e Educação Infantil, assim como ainda temos uma professora com Magistério a nível médio. Portanto, compreendemos que são necessárias políticas de formação docente para aqueles que ainda não possuem formação inicial para atuar na Educação Básica, conforme preconiza a Lei de Diretrizes e Bases da Educação Nacional $($ LDB n० 9.394/96) 5 .

\footnotetext{
${ }^{5}$ Art. 62. A formação de docentes para atuar na educação básica far-se-á em nível superior, em curso de licenciatura, de graduação plena, em universidades e institutos superiores de educação, admitida, como formação mínima para o exercício do magistério na educação infantil e nos 05 (cinco) primeiros anos do ensino fundamental (LDB 96)
}

@rquivo Brasileiro de Educação, Belo Horizonte, v. 6, n. 14, mai-ago, 2018. 


\subsection{Análises dos dados}

A análise ocorreu, primeiramente, pela organização e tabulação das respostas oriundas do questionário por aproximação de discurso das respostas entre os entrevistados, em que os discursos mais expressivos foram transcritos parcial ou totalmente, respeitando a originalidade da escrita. Em seguida, foi realizada a análise e interpretação desses discursos a partir de Orlandi $(1999,2008)$. Para ela, na análise do discurso não há sentido sem interpretação, uma vez que a interpretação está inter-relacionada ao discurso de quem fala e de quem analisa; cuja finalidade não é interpretar, mas compreender como um texto funciona, ou seja, como um texto produz sentido.

Assim, organizamos a síntese dos sentidos dos discursos produzidos pelos professores sobre 0 papel da escola para 0 enfrentamento da violência sexual contra crianças com base em Orlandi (2008). O autor defende que a construção do sentido, é determinada por fatores sócio-históricos e culturais e, principalmente, ideológicos atravessado por diferentes formações discursivas.

\section{QUADRO 2 - Sentidos dos discursos produzidos pelos professores sobre o papel da escola para o enfrentamento da violência sexual contra crianças}

\begin{tabular}{|c|c|c|}
\hline EIXOS & TEMÁTICAS & - $\quad$ SENTIDOS DOS DISCURSOS \\
\hline $\begin{array}{c}\text { A escola e o } \\
\text { enfrentamento à } \\
\text { violência sexual contra } \\
\text { crianças }\end{array}$ & $\begin{array}{l}\text { Concepção de } \\
\text { professores sobre a } \\
\text { violência sexual }\end{array}$ & $\begin{array}{l}\text { - É todo e qualquer ato ou tentativa de um } \\
\text { indivíduo, sem a permissão do parceiro; } \\
\text { - } \quad \text { Adentrar na intimidade do outro, gerando um } \\
\text { desconforto; } \\
\text { - } \quad \text { Ato desumano, ausência de moral, caráter e } \\
\text { respeito; } \\
\text { - } \quad \text { Abuso do corpo, não somente através do } \\
\text { - } \quad \text { Ato sexo, mas carícias sem consentimento; } \\
\text { - }{ }^{-} \text {ou tentativa sem o consentimento. }\end{array}$ \\
\hline & $\begin{array}{l}\text { Formação inicial e } \\
\text { continuada sobre a } \\
\text { violência sexual na } \\
\text { escola }\end{array}$ & $\begin{array}{l}\text { - A escola não proporcionou nenhuma } \\
\text { formação específica sobre violência sexual; } \\
\text { - } \quad \begin{array}{l}\text { Outros discursos apontam algumas } \\
\text { orientações e formação, com os temas }\end{array}\end{array}$ \\
\hline
\end{tabular}

@rquivo Brasileiro de Educação, Belo Horizonte, v. 6, n. 14, mai-ago, 2018. 


\begin{tabular}{|c|c|c|}
\hline \multirow{4}{*}{$\begin{array}{l}\text { Formação de } \\
\text { Professores e o } \\
\text { enfretamento da } \\
\text { violência sexual na } \\
\text { escola }\end{array}$} & & família e escola. \\
\hline & $\begin{array}{l}\text { Casos na escola de } \\
\text { crianças que foram } \\
\text { abusadas e as } \\
\text { medidas tomadas } \\
\text { pelos professores }\end{array}$ & $\begin{array}{l}\text { - Ocorreu casos na escola de crianças que } \\
\text { sofreram abuso sexual; } \\
\text { - As medidas centraram-se na comunicação a } \\
\text { família e delegação a mesma de } \\
\text { responsabilidade pelas medidas cabíveis, } \\
\text { além disso diálogo com a criança, } \\
\text { participação aos pais e Conselho Tutelar. }\end{array}$ \\
\hline & $\begin{array}{c}\text { Papel da escola para } \\
\text { o enfretamento da } \\
\text { violência sexual }\end{array}$ & 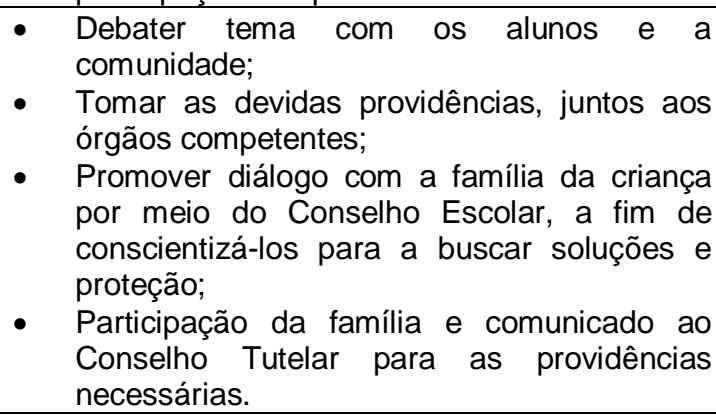 \\
\hline & $\begin{array}{l}\text { Percepção de } \\
\text { professores sobre } \\
\text { manifestação de } \\
\text { sentimento da } \\
\text { criança vítima de } \\
\text { violência sexual }\end{array}$ & $\begin{array}{l}\text { - Sentimento de tristeza, falta de afetividade, } \\
\text { insegurança, frustação mediante as outras } \\
\text { crianças no ambiente escolar; } \\
\text { - Outros discursos revelam que nunca } \\
\text { perceberam nenhum sentimento diferente na } \\
\text { criança. }\end{array}$ \\
\hline \multirow{3}{*}{$\begin{array}{c}\text { ECA, Redes de } \\
\text { Proteção à criança } \\
\text { vítima de abuso sexual } \\
\text { e a Escola }\end{array}$} & $\begin{array}{c}\text { O conhecimento de } \\
\text { professores sobre o } \\
\text { ECA }\end{array}$ & $\begin{array}{l}\text { - } \text { Alguns discursos revelam que existe } \\
\text { conhecimento sobre o ECA, outros em parte } \\
\text { e há também aqueles que não conhecem; } \\
\text { O ECA profere a proteção à criança e } \\
\text { adolescente, respeito a não ter seus direitos } \\
\text { violados, principalmente de vivenciar sua } \\
\text { infância e representa um Órgão que rege os } \\
\text { direitos da criança e do adolescente. }\end{array}$ \\
\hline & $\begin{array}{l}\text { O trabalho da escola } \\
\text { com as Rede de } \\
\text { Proteção à criança } \\
\text { vítima de abuso }\end{array}$ & $\begin{array}{l}\text { - A escola faz parte de um conjunto de Órgãos } \\
\text { que tem a responsabilidade de proteger a } \\
\text { criança e ao adolescente contra qualquer } \\
\text { forma de abuso; } \\
\text { - Para alguns professores não existe Rede de } \\
\text { Proteção. } \\
\text { - A escola em si trabalhou esse tema de forma } \\
\text { global, mas não voltado diretamente as } \\
\text { famílias. }\end{array}$ \\
\hline & $\begin{array}{c}\text { Ação pedagógica } \\
\text { voltada para crianças } \\
\text { vítimas de abuso }\end{array}$ & $\begin{array}{l}\text { - Não existe ação pedagógica para crianças } \\
\text { vítimas de abuso. }\end{array}$ \\
\hline
\end{tabular}

Fonte: Elaborado pela autora com em dados da pesquisa.

Assim, abordamos no primeiro momento uma breve incursão sobre a escola e o enfrentamento à violência sexual contra crianças e, no segundo, realizamos uma análise acerca dos discursos de professores e o papel da escola para o enfrentamento da violência sexual contra crianças no Ensino Fundamental em Augusto Corrêa-PA. 


\section{RESULTADOS E DISCUSSÃO}

\subsection{0s discursos dos professores sobre a violência sexual contra crianças}

A violência sexual incide, não só a uma violação à liberdade sexual do outro, mas também numa violação dos direitos humanos da criança, quando cometida contra criança, constitui crime grave, deixando cicatrizes profundas. Romero (2007) corrobora que a violência sexual na infância é o contato entre criança e um adulto que se utiliza dela para sua satisfação pessoal; sendo que esse ato interfere em todo seu desenvolvimento e um dos principais aspectos desse problema é que, na maioria das vezes, seu abusador encontra-se no mesmo espaço que a criança, é alguém conhecido por ela e sua família, se tornando assim a pior forma de violência.

A violência sexual contra crianças é um crime contra a vida e liberdade, sendo uma realidade global, um grande desafio para a escola. O abuso ocorre quando:

[...] um sujeito em condições de superioridade (idade, força, posição social ou econômica, inteligência, autoridade) comete um ato ou omissão capaz de causar dano físico, psicológico ou sexual, contrariamente à vontade da vítima ou por consentimento obtido a partir de indução ou sedução enganosa" (PIRES; MIYAZAKI, 2005, p. 44).

Desse modo, retira a própria dignidade do outro, em que, suas próprias vontades não são levadas em consideração. Nesse sentido, "[...] O abuso sexual contra crianças e adolescentes é um relacionamento interpessoal sexualizado, privado, de dominação perversa, geralmente mantida em silêncio e segredo" (FALEIROS; FALEIROS, 2007, p. 39).

@rquivo Brasileiro de Educação, Belo Horizonte, v. 6, n. 14, mai-ago, 2018. 
Nos discursos das professoras o Ensino Fundamental violência sexual é:

\begin{abstract}
É todo e qualquer ato ou tentativa de um indivíduo, sem a permissão do parceiro ou parceira no sentido a adentrar na intimidade do outro, gerando um desconforto (Professor A, Questionário, 2017).

É um ato desumano, onde há ausência de moral, caráter e respeito (Professor B, Questionário, 2017).

É o abuso do nosso corpo, não somente através do sexo, mas sim qualquer tipo de carícias sem o consentimento (Professor C, Questionário, 2017).

É todo e qualquer ato sexual ou tentativa sem o consentimento do outro (Professor D, Questionário, 2017).
\end{abstract}

Nesses discursos observa-se que os professores têm conceito formando sobre a violência sexual, o qual é compreendido como violação de direitos. Eles expressam que a violência sexual é adentrar na intimidade do outro, sendo um ato desumano, um abuso do corpo e uma tentativa sem consentimento que gera desconforto, uma ausência da moral e do respeito.

Para Faleiros e Faleiros (2008) a violência sexual contra crianças e adolescentes é uma violação de direitos, uma transgressão, uma relação de poder perversa e desestruturante. É necessário que os docentes, bem como todo corpo escolar, conheçam profundamente o que é a violência sexual e o que ela acarreta na vida daquele que sofre abuso, pois possuindo conhecimento sobre o conceito de abuso sexual, é possível tomar medidas necessárias para o seu enfrentamento.

Nesse sentido, Barros (2016, p.106) afirma:

Conhecer cada conceito pertinente ao fenômeno, objetivando abordá-los, entendendo seus significados, da mesma forma que, busca compreender que significados essas práticas de violência incidem sobre a vida das crianças e dos adolescentes, em especial quando advêm de uma simbologia

@rquivo Brasileiro de Educação, Belo Horizonte, v. 6, n. 14, mai-ago, 2018. 
cultural da supremacia do poder do adulto sobre os sujeitos vitimizados (BARROS, 2016, p.106).

Barros (2016) assegura que é fundamental que as escolas busquem informações das diferentes formas de violência sexual existentes contra a criança e adolescente. A escola, enquanto espaço de socialização, precisa, não somente a partir de novas metodologias de ensino, contribuir para a garantia do direito a uma educação de qualidade, mas a partir de questionamentos dos discursos explícitos ou implícitos presentes nas práticas cotidianas que se inscrevem na vida dos educandos.

A escola é um espaço onde os direitos das crianças devem ser respeitados, um lugar que se combata qualquer forma de violência, sabendo que as crianças e os adolescentes são vulneráveis a todo tipo de violência. Portanto, é necessário buscar apoio na legislação brasileira Constituição Federal (CF/88), (LDB n 9.394/96, ECA, entre outros) que assegurem que nenhuma criança ou adolescente pode ser objeto de negligência ou maltrato (FALEIROS; FALEIROS, 2008).

Em síntese, a violência sexual nos discursos de professores representa desconforto, ato desumano, amoral, abuso do corpo e ato sexual sem consentimento que fere a integridade humana, que não está voltado apenas para a relação sexual, mas tudo aquilo que não respeita o limite do outro.

Segundo a Associação Brasileira Multiprofissional de Proteção à Infância e a Adolescência (ABRAPIA, 2002) a violência sexual ou abuso sexual é a situação em que uma criança ou adolescente é usado para gratificação sexual de um adulto ou mesmo de um adolescente mais velho; baseado numa relação de poder que pode incluir desde carícias, manipulação das genitálias, mama ou anus, até o ato sexual com ou sem penetração.

@rquivo Brasileiro de Educação, Belo Horizonte, v. 6, n. 14, mai-ago, 2018. 
Diante dos conteúdos conceituais sobre a violência sexual, é basilar compreendermos o papel da escola frente a formação continuada dos professores, os casos de abuso e seu enfrentamento diante da função social da escola e a legislação brasileira.

\subsection{Os discursos dos Professores sobre a experiência vivida e o papel da escola}

No processo histórico de violência contra crianças, percebemos que esta passa inúmeras vezes despercebida, deixando a criança mais vulnerável a esse tipo de agressão e, mesmo com os avanços na educação em relação à discussão dessa temática, há muito que melhorar. Pois, existem diversos limites que precisam ser superados, principalmente porque ainda se percebe que não há um trabalho efetivo de formação dos professores voltado para fomentar a inclusão, no currículo escolar. Referente às temáticas de gênero: identidade de gênero, raça e etnia, religião, orientação sexual, pessoas com deficiência, bem como a todas as formas de discriminação e violações de direitos, assegurando formação aos trabalhadores da educação para lidar criticamente com tais temas.

Para Brino e Williams (2013) a escola é o principal meio para reconhecer uma criança vítima de abuso sexual, já que, na maioria das vezes, o abusador é alguém que mora na mesma casa, contribuindo para que, na maioria dos casos, o abuso permaneça em sigilo, pois em diversas ocasiões, a criança vítima da violência não consegue relatar o fato que dificilmente deixa marcas físicas.

O abuso sexual é um dos segredos mais "bem guardado", sendo mais difícil para avaliar uma vítima. Para Faleiros e Faleiros (2008) a violência sexual tem permanecido camuflada, poucos querem falar,

@rquivo Brasileiro de Educação, Belo Horizonte, v. 6, n. 14, mai-ago, 2018. 
inclusive no âmbito escolar. No estudo em questão os discursos de professores revelam que a escola não tem realizado formação continuada para o enfretamento da violência sexual e, quando realizada, se centram em temáticas voltadas para as questões relacionadas à família e à escola.

O papel dos professores é fundamental, pois pode contribuir decisivamente para o estabelecimento de práticas educativas que ensejem discussões, atitudes e a construção de posicionamentos refratários às violências simbólicas, às discriminações, aos preconceitos, à violação da dignidade humana.

Os casos de abuso sexual na escola foi objeto de questionamento aos professores do Ensino Fundamental. A esse respeito indagamos: Você já identificou, na escola, algum caso de abuso sexual contra criança? As respostas seguiram as seguintes alternativas: Sim, Não e Que medidas você tomou?

\footnotetext{
Sim. Foi chamada a família da adolescente e colocada a par da situação e passando a ela a responsabilidade de tomar as medidas necessárias (Professor A, Questionário, 2017).

Sim. Iniciei um diálogo com a criança (Professor B, Questionário, 2017).

Sim. A escola participou aos pais, que por sua vez comunicou o conselho tutelar (Professor C, Questionário, 2017).

Sim. (Professor D, Questionário, 2017).
}

Nos discursos dos professores A, B, C e D pode se perceber que todos identificaram casos de abuso contra crianças na escola. Porém, as medidas foram distintas, vejamos: comunicado à família acerca da situação (Professor A); diálogo com a criança (Professor C); participação da situação de violência aos pais e Conselho Tutelar (Professor C) e apenas a identificação do caso sem medidas de enfrentamento (Professor D).

@rquivo Brasileiro de Educação, Belo Horizonte, v. 6, n. 14, mai-ago, 2018. 
A despeito das medidas de enfrentamento, inferimos que apenas o diálogo com a criança, ou somente o comunicado aos pais não é suficiente. É necessário que a escola tenha projetos de combate à violência e estes estejam inseridos dentro Projeto Político Pedagógico, salas de aulas, plano de ensino, entre outros, para se trabalhar com as crianças e, ao detectar o problema, é necessário repassar aos órgãos competentes.

Para Inove e Ristum (2008, p.15) a "[...] atuação do professor na identificação e denúncia da violência sexual é fundamental, principalmente nas primeiras séries, quando passam cerca de quatro horas diárias com as crianças". E em relação ao Professor D, mesmo percebendo que na escola havia casos de abuso, não tomou nenhuma atitude, tornando-se negligente, como se não tivesse nenhuma relação com o problema. Pode-se perceber também que parte desses professores deixou a responsabilidade toda para a família, no entanto a escola tem por obrigação de denunciar os casos suspeitos.

Diante dessas medidas tomadas pelos professores acerca da identificação de casos na escola de crianças que foram abusadas, questionamos: Para você qual o papel da escola no enfrentamento de casos de violência sexual contra criança? Os professores ao serem questionados sobre essa problemática responderam:

Primeiramente a escola tem que debater o tema com os alunos e a comunidade e mediante casos que acontecem tomar as devidas providencias juntos aos órgãos competentes (Professor A, Questionário, 2017).

Na minha concepção, o Conselho da Escola deve promover um diálogo com a família da criança, a fim de conscientizá-los fazendo uma reflexão do assunto e buscar soluções para protegê-las (Professor B, Questionário, 2017).

É tomar soluções cabíveis, tal como participação da família, ou caso contrário comunicar o Conselho Tutelar. (Professor C, Questionário, 2017).

@rquivo Brasileiro de Educação, Belo Horizonte, v. 6, n. 14, mai-ago, 2018. 
Do meu ponto de vista a escola tem um papel fundamental em relação a esse tipo de violência ao detectar cabe a ela tomar as providências necessárias (Professor D, Questionário, 2017).

A professora A acredita que o papel da escola é realizar debates com a comunidade escolar e, diante de casos de violência sexual, tomar providências junto aos órgãos competentes. Os Professores B e C, por sua vez, delegam a responsabilidade ao Conselho Escolar e à família na busca de soluções para os casos de violência sexual, enquanto o Professor D aponta que o papel da escola é imprescindível para detectar o problema e tomar as devidas providências.

Para Landini (2011, p.97-98) "[...] discutir a violência sexual significa, necessariamente, discutir sexualidade [...]. Pensar possíveis soluções para o problema da violência sexual implica pensar crianças e adolescentes como sujeitos ativos". Para ele, "[...] proteger da violência e do abuso não significa isolá-los do mundo (real e virtual), mas prepará-los para lidar com essas situações. Para tanto, a abertura para falar sobre sexualidade é imprescindível".

Percebe-se a importância de relacionar a violência sexual com a sexualidade, de discutir e preparar as crianças e os adolescentes para situações reais de violência; no sentido de que saibam lidar com tais situações ao invés de fugirem e admitirem o pacto de silêncio que, costumeiramente, envolve vítimas de abuso sexual (VAGLIAT; GAGLIOTTO, 2013).

Nesse sentido, Barros (2016, p.45) assegura:

A escola tem papel fundamental no processo de enfrentamento contra a violação dos direitos desses sujeitos e, - combate à violência sexual é uma das pautas que precisa fazer parte da rotina da escola. Necessário se faz que a escola conheça e compreenda as tramas históricas, culturais e de poder que permeiam o problema, com o objetivo de intervir positivamente para o empoderamento dos sujeitos vitimizados e de suas famílias.

@rquivo Brasileiro de Educação, Belo Horizonte, v. 6, n. 14, mai-ago, 2018. 
A escola precisa combater esse tipo de violência tornando-se porta voz daquelas que são vimitizadas, trazendo para a rotina da escola pautas sobre abuso sexual e maneiras de combatê-las e, assim, possibilitar que todos possam ter conhecimento sobre esse assunto. Desta forma, o discurso dos professores sobre o papel da escola diante da violência sexual constitui-se como o de conscientizador, a partir de três estratégias:

a) Participação da família e conselho tutelar;

b) Diálogo com conselho escolar;

c) Debate com os alunos.

Esses discursos revelam que, na visão dos professores, a escola tem contribuído para o enfrentamento da violência sexual, mas apenas na perspectiva da prevenção, sem uma visão no campo da denúncia e ou intervenção, para a garantia da integridade física e emocional da criança ou adolescente. O que vai implicar na ausência de estratégia para proteção legal e social. Nesse sentido, é necessário considerar que para além da conscientização denunciar e identificar a violência sexual implica, contudo, ações reflexivas junto aos professores, fundamentadas em discussões teóricas. Isso pode contribuir para a sensibilização dos docentes, possibilitando 0 enxergar e o saber trabalhar com 0 indesejado que se constitui a violência sexual (VAGLIAT; GAGLIOTTO, 2013).

Faleiros e Faleiros (2008) ressalta que a escola é um ambiente privilegiado para a construção da cidadania, e um convívio harmonioso deve ser capaz de garantir o respeito aos direitos humanos e educar a todos no sentido de impedir as manifestações da violência. É necessário que a escola seja um espaço harmonioso, que garanta o direito à vida;

@rquivo Brasileiro de Educação, Belo Horizonte, v. 6, n. 14, mai-ago, 2018. 
ofereça segurança e também conheça as maneiras de manifestações de violência sexual contra crianças para poder detectar o problema, tanto no espaço escolar quanto em outro campo social, sendo esse espaço educacional privilegiado para observar e conhecer essas vítimas e assim fazer o encaminhamento destas para os órgãos competentes.

Sendo o espaço escolar um local propício para observar e interagir com a criança, os professores foram questionados: Você já percebeu alguma manifestação de sentimento da criança vítima de violência sexual? A esse respeito os discursos dos professores revelaram:

\footnotetext{
Um sentimento de tristeza e falta de afetividade (Professor A, Questionário, 2017).

Um sentimento de insegurança (Professor B, Questionário, 2017).

Sentimento de frustração mediante as outras crianças no ambiente escolar ((Professor C, Questionário, 2017).

Nunca percebi esse sentimento (Professor D, Questionário, 2017).
}

Percebe-se que, tanto o Professor A e B quanto o C, observaram que as crianças vítimas de violência sexual havia um sentimento ruim, de tristeza, de falta de afeto, de insegurança e frustração mediante o seu convívio no espaço escolar, enquanto que o Professor D não observou nenhum tipo de reação.

É importante que o professor saiba perceber qualquer tipo de sentimento que as crianças transmitem que causam mal-estar. Pois, é necessário observar o comportamento do aluno para compreender o que se passa com ele, sabendo que são muitas consequências tanto emocionais quanto cognitivas e sociais.

Nesse sentido, Borges (2007, p.13) ressalta:

Crianças vítimas de ASI podem apresentar sentimento de

@rquivo Brasileiro de Educação, Belo Horizonte, v. 6, n. 14, mai-ago, 2018. 
culpa, dificuldade de confiar no outro, comportamento hipersexualizado, medo, pesadelo, isolamento, sentimento de desamparo e ódio fugas de casa, baixa autoestima, sintomas somáticos, agressividade, entre outros sintomas.

Observa-se que uma criança abusada traz consigo diversas consequências que ao longo de sua vida pode ser manifestada, sendo necessária a observação e ajuda, pois este é um sujeito de direitos e precisa ser respeitado como estabelece a CF/88 e o ECA.

\subsection{Discursos sobre as Redes de Proteção à criança vítima de abuso sexual e a escola}

O ECA é um marco essencial para orientar a sociedade sobre os direitos das crianças e adolescentes, pois, antes não eram vistos como sujeitos de direitos, após sua construção, elas já nascem com direitos e deve receber atenção da família e de toda sociedade, pois é necessário que cresça, desenvolva e tenha qualidade de vida.

O ECA, em seu artigo 227, estabelece que é dever da família, da sociedade e do estado assegurar à criança e ao adolescente, com absoluta prioridade, o direito à vida, a saúde a alimentação, a educação, ao lazer, a profissionalização, a cultura, a dignidade, ao respeito, a liberdade e a convivência familiar e comunitária, além de colocá-las salvo de toda forma de negligência, discriminação, exploração, violência, crueldade e opressão.

Os professores ao serem questionados sobre o ECA, tendo em vista as questões a seguir: Você conhece o Estatuto da Criança e do adolescente a respeito do abuso sexual? Sobre essa questão enunciaram:

Sim. O ECA no contexto geral protege a criança e ao adolescente, mas não conheço no que diz respeito ao abuso sexual (Professor A, Questionário, 2017).

@rquivo Brasileiro de Educação, Belo Horizonte, v. 6, n. 14, mai-ago, 2018. 
Sim. (Professor B, Questionário, 2017).

Sim. Toda criança merece ser respeitada e não ter seus direitos violados, principalmente de vivenciar sua infância (Professor C, Questionário, 2017).

Conheço em parte, é um órgão que rege os direitos da criança e do adolescente (Professor D, Questionário, 2017).

De acordo com as respostas dos professores A, C e D verificouse que eles possuem, em parte, certo conhecimento sobre o ECA, no entanto, é um saber limitado quando diz respeito a violência sexual contra crianças. Já o Professor B revela que conhece o ECA, mas não manifestou opinião sobre o assunto abordado, sendo assim, ambos não apresentam respostas tão significativas sobre o tema e não possuem o conhecimento específico acerca dos dispositivos que versam sobre a violência sexual expressas nesse Estatuto.

O ECA e outros documentos internacionais estabelecem, dentre outros conhecimentos, que o abuso sexual, para além de crime contra liberdade sexual, é considerado como violação dos direitos humanos. A esse respeito Martinelli $(2013$, p.10) afirma:

[...] ECA, juntamente com outras normas e acordos internacionais, fez com que o abuso sexual contra crianças e adolescentes deixasse de ser somente um crime contra a liberdade sexual e se transformasse numa violação dos direitos humanos.

O ECA é um grande passo para afirmação dos direitos da criança que, até então, era exposta a todo tipo de violência, elevado a sujeitos de direitos e a necessidade de serem respeitadas por se encontrarem em condição peculiar de pessoas em desenvolvimento, sendo, portanto, vulneráveis e merecedoras de tutela prioritária.

Segundo Faleiros e Faleiros (2008, p.31) a violência, de qualquer tipo, contra crianças e adolescentes "[...] é uma relação e poder na

@rquivo Brasileiro de Educação, Belo Horizonte, v. 6, n. 14, mai-ago, 2018. 
qual estão presentes e se confrontam atores/forças com pesos/poderes desiguais, de conhecimento, força, autoridade, experiência, maturidade, estratégias e recursos".

A Lei 12.015/2009 ocasionou mudanças significativas no Título denominado Crimes Contra os Costumes, agora intitulado como Crimes Contra a Dignidade Sexual. Tal alteração na nomenclatura do Título VI do Código Penal não foi por acaso, buscou-se dar mais modernidade aos delitos sexuais.

A respeito dos avanços, sabe-se que ainda a muito a ser feito para mudar a realidade da violência sexual infantil, pois apesar dos avanços com pesquisas e denúncias, "[...] somente nos dias de hoje, frente à consciência da relevância dos direitos humanos, tornou-se prioridade combatê-la" (BALBINNOTTI, 2009, p.3); noticiários deixam claro que, a cada dia, há diversos casos de abuso e violência sexual, fora os inúmeros casos que ficam às escondidas, que, em sua maioria, são crianças e mulheres. A violência sexual é o uso da criança para obtenção de prazer, de necessidades ou de desejos sexuais, sendo esta incapaz de interferir na ação por qualquer motivo, seja pelo poder sobre ela ou qualquer outro motivo.

Para Labodesca e Onofre (2010, p.4) o abuso sexual pode envolver:

[...] violência direta, e ocorrer em diferentes formas, seja por meio de contato físico direto (beijos, masturbação, relação sexual, entre outros) ou por via indireta (encorajar a criança a assistir contatos sexuais ou ouvi-los, observar a criança nua ou despindo-se, fotografar a criança para uso erótico posterior, expor a genitália deliberadamente, entre outros).

É preciso que desde cedo as crianças aprendam o que é a violência sexual, tenham conhecimento sobre as formas e os tipos de violência, como também os tipos de abusos. Para que assim, possam denunciar que não sejam mais vitimadas, e não se calem diante dos

@rquivo Brasileiro de Educação, Belo Horizonte, v. 6, n. 14, mai-ago, 2018. 
fatos. Um dos problemas em não haver a denúncia aos órgãos competentes é que, muitas vezes, não existe confiabilidade nos relatos das crianças e esta é vista apenas como sujeito que inventa história ou mesmo conta mentiras e, assim, podemos ver seus reflexos que geralmente causa mal a criança.

É válido ressaltar que inúmeras vezes, "[...] o preconceito e a tendência social em não dar credibilidade à palavra da criança é um dos principais obstáculos ao enfrentamento da violência sexual contra crianças e adolescentes" (LABODESCA; ONOFRE, 2010, p.12). Faz-se necessário conhecer o que trata a Lei a respeito dos direitos das crianças e adolescentes no tocante a violência sexual, sobretudo, a responsabilização dos agressores, a proteção e acolhimento das vítimas de abuso sexual.

Para que esses direitos sejam colocados em prática é preciso toda uma Rede de Proteção, incluindo diversos setores como: Conselho Tutelar, Juizado de Infância e Adolescência, escolas, hospitais e Promotoria, se mobilizem para enfrentar esse problema social, que também ocorre em rede. Para Faleiros e Faleiros (2008, p.80) a Rede de Proteção a Criança e Adolescente "[...] é o conjunto social constituído por atores e organismos governamentais e não governamentais, articulado e construído com o objetivo de garantir os direitos gerais ou específicos de uma parcela da população infanto-juvenil".

Para Ferreira (2010. p.204) o trabalho em Rede significa:

[...] um mecanismo eficaz para a interrupção da violência, favorece uma visão ampliada das situações, permite que se planejem ações integradas e é uma forma de compartilhar responsabilidades sobre os casos, permitindo que cada setor atue com foco nas questões que lhe cabem.

A formação de uma rede é um grande desafio e requer que todos os envolvidos estejam realmente comprometidos, e esse

@rquivo Brasileiro de Educação, Belo Horizonte, v. 6, n. 14, mai-ago, 2018. 
envolvimento se produza por vínculos afetivos que foram aos poucos se constituindo e, assim, estejam preparados para que o atendimento seja eficaz.

Durante a realização da pesquisa com os professores do Ensino Fundamental também questionamos sobre as Redes de Proteção à criança e ao adolescente. Assim, indagamos: A escola trabalha com a rede de proteção às crianças vítimas de abuso? Quais? A esse respeito enunciaram:

\footnotetext{
A escola faz parte de um conjunto de órgãos que tem a responsabilidade de proteger a criança e o adolescente contra qualquer forma de abuso, no entanto não vejo esse tema ser bem tratado. (Professor A, Questionário, 2017).

Não (Professor B, Questionário, 2017).

Não (Professor C, Questionário, 2017).

A escola em si trabalhou esse tema de forma global, mas não voltado diretamente as famílias (Professor D, Questionário, 2017).
}

Pode-se observar no discurso do Professor A que a Rede de Proteção é representada por um conjunto de órgãos, mas revela que a discussão sobre a violência sexual na escola é ausente. Nos discursos dos Professores B e C não existe Rede de Proteção à criança vítima de abuso, o que se evidencia é a ausência de articulação da escola com atores, organismos governamentais e não governamentais para a garantia dos direitos da criança. Em relação ao Professor D não há uma clareza do que seja Rede de Proteção às crianças, apenas aponta a discussão dessa temática de forma generalizada sem ampliação para o âmbito da família.

A escola ocupa um papel importante na garantia de direitos, de modo a contribuir para a prática da cidadania e da participação. Segundo Faleiros e Faleiros (2008, p.86) "[...] a Escola tem também a

@rquivo Brasileiro de Educação, Belo Horizonte, v. 6, n. 14, mai-ago, 2018. 
função de Atendimento, ou seja, de proteger seus estudantes crianças e adolescentes contra qualquer violação de seus direitos e de oportunizar a eles condições de pleno desenvolvimento escolar, mental, psicológico, sexual, moral e social". No entanto, PROSSEGUEM OS AUTORES, "[...] essas responsabilidades não são exclusivas da Escola, mas de toda a Rede de Proteção, da qual ela é parte integrante e na qual tem papel preponderante".

A escola, como formadora, tem um papel fundamental na desconstrução da violência simbólica e da cultura da inferiorização de gênero, de raça, de classe social e de geração (Faleiros e Faleiros, 2008), além de ter como obrigação denunciar casos de suspeitas de violência ao Conselho Tutelar. De acordo com o ECA, Capítulo II - Das Infrações Administrativas, artigo 245:

\begin{abstract}
Deixar o médico, professor ou responsável por estabelecimento de atenção à saúde e de ensino fundamental, pré-escola ou creche, de comunicar à autoridade competente os casos de que tenha conhecimento, envolvendo suspeita ou confirmação de maus-tratos contra criança ou adolescente" é uma infração administrativa, sob pena de "multa de três a vinte salários de referência, aplicando-se o dobro em caso de reincidência.
\end{abstract}

O ECA no ambiente escolar é um grande avanço, por isso temos a obrigação de conhecer e vivenciar essa legislação de modo a refletir sobre o papel da escola para além da mera instrução formal, mas sobretudo, como forma de contribuir para a proteção da criança ou adolescente, pois a desinformação, aliada ao medo de envolvimento em situações conflitivas, pode fazer com que as pessoas se omitam e, desta forma, a maioria dos casos de abuso infantil permanece oculto e sem assistência.

É preciso fazer uma releitura do Projeto Político Pedagógico da Escola e inserir nessa proposta pedagógica ações de enfrentamento à violência sexual, uma vez que, a obrigatoriedade do ECA, não é

@rquivo Brasileiro de Educação, Belo Horizonte, v. 6, n. 14, mai-ago, 2018. 
apenas da escola, mas de agentes, organismos governamentais e não governamentais (federal, estadual e municipal), com diferentes funções, objetivos e instrumentos de ação.

As ações de enfrentamento exigem, portanto a participação efetiva dos Organismos do Sistema de Garantia dos Direitos da Criança e dos Adolescentes, como: os Conselhos dos Direitos da Criança e do Adolescente; Conselhos Tutelares; Fundos dos Direitos da Criança e do Adolescente; Varas da Infância e da Juventude; Promotorias da Infância e Juventude; Delegacias de Proteção à Criança e ao Adolescente (DPCA); Fóruns dos Direitos da Criança e do Adolescente (Fórum DCA); Centros de Defesa; Defensoria Pública; Secretarias de governo estaduais e municipais executoras de políticas públicas; bem como Organizações não governamentais (ONG's).

Apesar das melhorias que já existem no tocante à legislação, percebe-se que pouco se conhece sobre as Redes de Proteção e, por vezes, a escola acaba ficando de fora dessa Rede; o que pode contribuir para a ausência de percepção das situações de abuso e informações sobre como proceder para a identificação das evidências de ocorrência do abuso na escola.

Ao discutir como a escola lida com a violência sexual, os estabelecimentos de ensino foram questionados: Na escola existe uma ação pedagógica direcionada para crianças vítimas de abuso? As respostas seguiram as alternativas: Às vezes, Nunca, Regulamente, Outros e Quais?

Não. Nunca teve (Professor A, Questionário, 2017).

Não. (Professor B, Questionário, 2017).

Não. A escola ainda não parou para organizar (Professor C, Questionário, 2017).

Não. (Professor D, Questionário, 2017).

@rquivo Brasileiro de Educação, Belo Horizonte, v. 6, n. 14, mai-ago, 2018. 
Percebe-se que os professores A, B, C e D afirmam que na escola nunca existiu ações pedagógicas voltadas para crianças vítimas de abuso sexual. Dessa maneira, consideramos necessário que se amplie as políticas públicas educacionais de enfrentamento à violência sexual contra crianças e adolescentes, bem como a reformulação do PPP e a execução de projetos e ações que tragam como objeto de discussão a proteção de crianças e adolescente contra qualquer violação de seus direitos.

A despeito das garantias democráticas, claramente expressas na CF/1988, ECA, dentre outros documentos legais, as políticas públicas descomprometidas com o princípio constitucional da prioridade absoluta às crianças e adolescentes, tornam o Estado um dos principais responsáveis pela violência estrutural (FALEIROS; FALEIROS, 2008).

Apesar da implementação de projetos a partir de ações do Governo Federal como Escola que Protege, Sentinela, Programa de Erradicação do Trabalho Infantil (PETI), Programa de Ações Integradas (PAIR), Referência de Enfrentamento à Violência Sexual Infanto-Juvenil no Território Brasileiro, dentre outros, ainda consideramos a urgência de programas e projetos que, de fato, contemple o trabalho pedagógico na escola e a formação de professores e demais agentes com subsídios que viabilizassem sua atuação como agentes fundamentais com vista a contribuir para a garantia dos direitos das crianças e adolescentes por meio do enfrentamento de desafios e da implementação de ações práticas no cotidiano escolar.

A esse respeito Martelli $(2013$, p. 11$)$ afirma:

A escola como "lócus" de transmissão-assimilação de conhecimentos sistematizados e produzidos na e pela sociedade, bem como socializadora de comportamentos, atitudes e hábitos sociais não pode se esquivar dessa responsabilidade para com as crianças e os adolescentes.

@rquivo Brasileiro de Educação, Belo Horizonte, v. 6, n. 14, mai-ago, 2018. 
As escolas frente a essa realidade possuem uma responsabilidade de organizar ações, contribuir com atitudes e hábitos para melhor trabalhar com as crianças e, sobretudo, aquelas vítimas de abuso sexual e assim, fazê-las crescer e se desenvolver. Contudo, é importante ressaltar que tais ações devem ser acompanhadas por uma formação que possibilite obter conhecimentos necessários para essa prática. Pois, "[...] a escola é um espaço privilegiado para a construção da cidadania, onde um convívio harmonioso deve ser capaz de garantir o respeito aos direitos humanos e educar [...] no sentido de evitar as manifestações de violência" (FALEIROS; FALEIROS, 2008).

De modo geral, percebemos que os sentidos dos discursos produzidos pelos professores sobre $\bigcirc$ papel da escola para $\bigcirc$ enfrentamento da violência sexual contra crianças, revelam que os mesmos apresentam conhecimentos sobre essa temática. Cujos sentidos expressam ato ou tentativa sem permissão do parceiro, significa adentrar na intimidade do outro ou desconforto, ato desumano, ausência de moral, abuso do corpo por meio do sexo, caricias e ato sexual sem consentimento.

No tocante a Formação inicial e continuada sobre a violência sexual na escola, os professores manifestaram que nunca receberam nenhuma formação específica sobre essa temática, no entanto, algumas orientações foram realizadas pela escola com temáticas voltadas para a família e escola.

Os professores, ao detectarem casos de abusos contra crianças, revelaram que comunicaram à família do adolescente, no entanto, delegaram a mesma a responsabilidade de tomar as medidas cabíveis. A escola para além da responsabilização da família realizou também diálogo com a criança, participação aos pais e Conselho Tutelar. Nesse caso a responsabilização não é somente da família, a garantia de

@rquivo Brasileiro de Educação, Belo Horizonte, v. 6, n. 14, mai-ago, 2018. 
direitos de crianças e adolescentes é responsabilidade de múltiplos organismos, governamentais e não governamentais, em nível federal, estadual e municipal, com diferentes funções, objetivos e instrumentos de ação.

A escola, mesmo considerando as fragilidades em relação as ações efetivas de enfrentamento à violência sexual, tem um papel basilar na proteção de crianças e adolescentes contra qualquer violação de seus direitos e de Ihes oportunizar condições de pleno desenvolvimento escolar, mental, psicológico, sexual, moral e social, conforme assegura a legislação brasileira (CF/88, ECA, LDB nº 9.394/96, entre outras).

$\mathrm{Na}$ percepção dos professores, o papel da escola para o enfretamento de casos de violência sexual, centra-se em debater sobre a temática com alunos e a comunidade; tomar providências junto aos órgãos competentes, bem como Conselho Escolar; o qual deverá promover um diálogo com a família da criança, a fim de conscientizálos e buscar soluções com o objetivo de protegê-las.

Os professores (alguns) no cotidiano da escola também percebem a criança que foi vítima de violência sexual, por meio de alguns sentimentos que são evidenciados no ambiente escolar, tais como: tristeza, ausência de afetividade, insegurança e frustração mediante as outras crianças no ambiente da escola. Todavia, outros também revelam que nunca perceberam nenhum sentimento diferente na criança, isso dificulta o combate à teia de violência que, muitas vezes, começa dentro de casa e em locais que deveriam: abrigar, proteger e socializar as crianças e adolescentes.

Em relação ao ECA, Redes de Proteção à criança vítima de abuso sexual e a escola, os professores revelam um (des)conhecimento acerca do ECA. Primeiramente, os discursos evidenciam que existe

@rquivo Brasileiro de Educação, Belo Horizonte, v. 6, n. 14, mai-ago, 2018. 
conhecimento sobre esse Estatuto, mencionam que o mesmo profere a proteção à criança e adolescente, respeito a não ter seus direitos violados, principalmente de vivenciar sua infância. Segundo compreendem o ECA como um Órgão que rege os direitos da criança e do adolescente, mas o Estatuto é uma legislação (Lei n $8.069 / 90$ ) que dispõe sobre a proteção integral à criança e ao adolescente. Em outros discursos existem aqueles que conhecem em parte essa legislação e ainda há outros que não a conhecem.

Tal desconhecimento sobre O ECA pode contribuir para a invisibilidade da criança vítima de violência sexual, sobretudo, ações de enfrentamento a qualquer forma de negligência, discriminação, exploração, violência, crueldade e opressão aos seus direitos fundamentais. O desconhecimento pode ainda inviabilizar a notificação (comunicação oficialmente), dentre outras medidas, aos órgãos competentes de todos os casos suspeitos ou confirmados de maus-tratos contra crianças e adolescentes por meio de profissionais e dirigentes das áreas de educação e de saúde, conforme institui o ECA.

Na percepção de professores do Ensino Fundamental, não existe uma Rede de Proteção à criança vítima de abuso, embora compreendam que a escola faz parte de um conjunto de Órgãos (não especificado) que tem a responsabilidade de proteger a criança e o adolescente contra qualquer forma de abuso. Portanto, trabalha com essa temática de forma global, mas não diretamente voltado para a discussão com as famílias. Além disso, não se evidenciou uma ação pedagógica voltada para crianças vítimas de abuso.

\section{CONSIDERAÇÕES FINAIS}

Esse trabalho teve como objetivo analisar os discursos de

@rquivo Brasileiro de Educação, Belo Horizonte, v. 6, n. 14, mai-ago, 2018. 
professores sobre o papel da escola para o enfretamento da violência sexual contra crianças no Ensino Fundamental em Augusto Corrêa-PA. Partimos da premissa que a escola é um local favorável para detecção, encaminhamento e apoio à criança que sofre abuso sexual, pois este submete a criança a atos que fere toda sua integridade, seja por meio das relações de poder desigual, força física, ameaça, sedução ou mesmo oferta de presentes.

Para realização dessa pesquisa foi elaborado um questionário semiestruturado para os professores dos anos iniciais do Ensino Fundamental sobre a violência sexual contra crianças na escola. Nesse sentido, abordamos acerca da formação inicial e continuada para o trato dessa temática, a identificação de casos na escola de crianças que foram abusadas e as medidas que foram tomadas, bem como 0 papel da escola para o enfrentamento da violência sexual e a percepção de professores sobre os sentimentos das crianças vítimas de abuso e, por fim, foi questionado sobre o ECA, as Redes de Proteção e as ações pedagógicas voltadas para crianças.

Após a análise do questionário identificamos os seguintes resultados da pesquisa:

1. Os professores compreendem a violência sexual contra crianças como ato ou tentativa sem permissão do parceiro. Significa adentrar na intimidade do outro, o que gera desconforto, ato desumano, ausência de moral, abuso do corpo por meio do sexo, carícias e ato sexual sem consentimento.

2. Os professores nunca receberam nenhuma formação específica sobre a temática da violência sexual, no entanto, algumas orientações foram realizadas pela escola, com temas voltadas para a família e escola.

@rquivo Brasileiro de Educação, Belo Horizonte, v. 6, n. 14, mai-ago, 2018. 
3. Segundo os professores, os casos de abusos contra crianças foram comunicados à família do adolescente, sendo que a esta delegada a responsabilidade pelas medidas cabíveis. A escola também realizou diálogos com a criança com a participação dos pais e Conselho Tutelar.

4. Na percepção dos professores, o papel da escola para $\circ$ enfretamento de casos de violência sexual ocorre por meio de debates sobre a temática com alunos e a comunidade, providências junto aos órgãos competentes, bem como Conselho Escolar.

5. Os sentimentos expressos pelas crianças no ambiente escolar se referem à tristeza, ausência de afetividade, insegurança e frustração mediante as outras crianças. Porém, outros também revelam que nunca perceberam nenhum sentimento diferente na criança vítima de abuso.

6. Em relação ao ECA, Redes de Proteção à criança vítima de abuso sexual e a escola os professores revelam um [des]conhecimento acerca do ECA. Primeiramente, os discursos evidenciam que existe conhecimento sobre esse Estatuto; segundo, compreendem o ECA como um Órgão que rege os direitos da criança e do adolescente, mas o Estatuto é uma legislação (Lei n 8.069/90) que dispõe sobre a proteção integral à criança e ao adolescente. Já em outros discursos existem aqueles que conhecem em parte e ainda há outros que não a conhecem.

7. Na percepção de professores do Ensino Fundamental, não existe uma Rede de Proteção à criança vítima de abuso, embora compreendam que a escola faz parte de um conjunto de Órgãos que tem a responsabilidade de proteger a criança e 0 
adolescente contra qualquer forma de abuso. Portanto, trabalha com essa temática de forma global e não diretamente voltado para a discussão com as famílias.

8. Para os professores não existe uma ação pedagógica voltada para crianças vítimas de abuso.

O papel da escola para o enfrentamento da violência sexual necessita de formação inicial e continuada que possibilite um conhecimento maior sobre o assunto, pois a escola é fundamental nesse tipo de ocorrência. Portanto, é essencial que os professores sejam capacitados e informados em relação aos conhecimentos básicos, legislação referente a temática e direitos da criança e do adolescente para que possa ocorrer intervenção e denúncia aos Órgãos competentes, pois, mesmo existindo conhecimentos de casos na escola, as medidas tomadas foram insuficientes.

É necessário que a escola se estabeleça como uma instituição fundamental na constituição da Rede de Proteção de direitos da criança e adolescente; já que é um dos principais Órgãos que compõe estratégias educacionais e de cuidado que dão acesso a um maior número de crianças. Contudo, há a ausência de articulação da escola no enfretamento ao abuso sexual, sobretudo ações efetivas, registros e outras medidas necessárias ao enfretamento da violência sexual no âmbito escolar.

O estudo conclui que as instituições escolares devem assumir a responsabilidade de enfrentamento do abuso sexual contra crianças, pois essa violência é, muitas vezes, camuflada pelo silêncio da própria vítima. Dessa maneira, faz-se necessário a articulação em rede de apoio e enfretamento, pois a formação da rede muda o olhar das instituições como órgãos centrais e hierárquicos (BRASIL, 2004). E, dessa

@rquivo Brasileiro de Educação, Belo Horizonte, v. 6, n. 14, mai-ago, 2018. 
forma, permite compartilhar responsabilidades e reivindicações por meio de objetivos e compromissos comuns, que é o bem-estar da criança e do adolescente.

\section{REFERÊNCIAS}

ASSOCIAÇÃO BRASILEIRA MULTIPROFISSIONAL DE PROTEÇÃO A INFÂNCIA E A ADOLESCÊNCIA Abuso sexual contra crianças e adolescentes: mitos e realidades. 3. ed. Petrópolis: Autores \& Agentes \& Associados, 2002.

AZEVEDO, Gabriela Azen; HABIGZANG, Luiza F; KOLLER, Silvia H; MACHADO, Paula Xavier. Abuso sexual infantil e dinâmica familiar:aspectos observados em processo jurídico. Psicologia: Teoria e Pesquisa, v. 21, n.21, p. 341 a 348, set./dez. 2005.

BALBINOTTI, Claudia. A violência sexual infantil intrafamiliar: a vitimização da criança e do adolescente vítima de abuso. Direito \& Justiça, v. 35, n. 1, p. 5-21, jan./jun. 2009. Disponível em: http://revistaseletronicas.pucrs.br/ojs/index.php/fadir/article/view/8207/ 5894. Acesso em: 20 fev. 2019.

BARROS, Marilene Maria Aquino Castro. A participação da escola no enfrentamento da exploração sexual contra crianças e adolescentes em municípios impactados por grandes projetos minero-metalúrgicos: um estudo de caso em juruti (PA).2016. 251f. Tese (Doutorado) Universidade Federal do Pará. Programa de Pós-Graduação em Educação. Belém-PA, 2016.

BORGES, Jeane Lessenge. Abuso sexual infantil: consequências cognitivas e emocionais. 2007.94 f. Dissertação (Mestrado) Universidade Federal do Rio Grande do Sul, Programa de PósGraduação em Psicologia, Porto Alegre, 2007.

BOTELHO, André; SCHWARCZ, Lilia Moritz. (org.). Cidadania, um projeto em construção: minorias, justiça e direitos. São Paulo: Claro Enigma, 2012.

BRASIL. Lei n8069, de 13 de julho de 1990. Estatuto da Criança e do Adolescente. Dispõe sobre o Estatuto da Criança e do Adolescente e dá outras providências. Diário Oficial da União, Brasília, 16 jul. 1990. Disponível em: http://www.planalto.gov.br/ccivil_03/LEIS/L8069.htm. Acesso em: 20 fev. 2019.

@rquivo Brasileiro de Educação, Belo Horizonte, v. 6, n. 14, mai-ago, 2018. 
BRASIL. Lei n9.394 de 20 de dezembro de 1996. Lei de diretrizes base da Educação Nacional. Estabelece as diretrizes e bases da educação nacional. Diário Oficial da União, Brasília, 23 dez. 1996. Disponível em: http://www.planalto.gov.br/ccivil_03/leis/L9394.htm. Acesso em: 20 fev. 2018.

BRASIL. Ministério da Educação. Guia escolar: métodos para identificação de sinais de abuso e exploração sexual de crianças e adolescentes. Brasília: Secretaria Especial dos Direitos Humanos, 2004.

BRINO, Rachel de Faria;WILLIAMS, Lúcia Cavalcanti de Alvuquerque. Concepções da professora acerca do abuso sexual infantil. Cadernos Pesquisa, n. 119, p. 113-128, 2003.

COSTA, Liana Fortunado; JUNQUEIRA, Eika Lôbo, MENESES, Fernanda Figueiredo Falcomer; STROHER, Lucy Mary Cavalcanti. As relações familiares do adolescente ofensor sexual. Psico USF, v. 18, n.1, p. 33-44, jan. / abr. 2013.

FALEIROS, Vicente de Paula; FALEIROS, Eva Silveira. A escola que protege enfrentando a violência contra crianças e adolescentes. 2 ed. Braślia: Secretaria de Educação Continuada, Alfabetização e Diversidade do Mistério da Educação, 2008.

FALEIROS, Vicente de Paula; FALEIROS, Eva Silveira. Escola que protege: enfrentando a violência contra crianças e adolescentes. Brasília: Ministério da Educação, 2007. Disponível em: http://portal.mec.gov.br/index.php?option=com_docman\&view=downl oad\&alias=638-vol-31-escqprotege-elet-

pdf\&category_slug=documentos-pdf\&ltemid=30192. Acesso em: $20 \mathrm{fev}$. 2019.

FERREIRA, Ana Lúcia. A escola e a rede de proteção de crianças e adolescentes. In: ASSIS, Simone Gonçalves de; CONSTANTINO, Patrícia; $A \bigvee A N C l$, Joviana Quintes, (org.). Impactos da violência na escola: um diálogo com professores. Rio de Janeiro: Ministério da Educação/ Editora FIOCRUZ, 2010. p. 203-234. Disponível em:http://books.scielo.org/id/szv5t/pdf/assis-9788575413302-10.pdf. Acesso em: 20 fev. 2018.

GODOY, Arilda Schmidt. Pesquisa qualitativa tipos fundamentais. Revista de Administração de Empresas, São Paulo, v.35, p. 20-29, 1995.

@rquivo Brasileiro de Educação, Belo Horizonte, v. 6, n. 14, mai-ago, 2018. 
INOUE, Silvia Regina Viodres; RISTUM, Marilena. Violência sexual: caracterização e análise de casos revelados na escola. Estudos de Psicologia. Campinas, v.25, n.1, p.11-21, 2008.

LABADESSA, Vanessa Milani; ONOFRE, Mariangela Aloise. Abuso sexual infantil: perspectivas na defesa dos direitos humano. Revista Olhar

Científico - Faculdades associadas de Ariquemes, v.1, n. 1, jan/jul. 2010.

LANDINI, Tatiana. S. O professor diante da violência sexual.São Paulo: Cortez, 2011.

LAVAREDA, Renata Pereira; MAGALHÃES, Thaís Quezado Soares. Violência sexual contra crianças e adolescentes: identificação e enfrentamento. Brasília: Ministério Público do Distrito Federal e Territórios. Núcleo de Enfrentamento à Violência e à Exploração Sexual de Crianças e Adolescentes, 2015.

LIMA, Joana Azevêdo; ALBERTO, Maria de Fátima Pereira. O olhar de mães acerca do abuso sexual intrafamiliar sofrido por suas filhas. Psicologia: ciência e profissão, v. 35, n. 4, out./dez. 2015. Disponível em: http://www.scielo.br/scielo.php?script=sci_arttext\&pid=\$141498932015000401157\&lng=pt\&tlng=pt. Acesso em: 20 fev. 2019.

MARTELLI, Andréa Cristina. Abuso sexual contra crianças e adolescentes: o que a escola tem a ver com isso? In: SIMPÓSIO INTERNACIONAL DE EDUCAÇÃO SEXUAL CORPO, IDENTIDADE DE GÊNERO E HETERONORMATIVIDADE NO ESPAÇO ESCOLAR, 3., 2013, Maringá-PR. Anais [...] Maringá-PR, 2013.

MARTINS, Rosimeire de Carvalho. Sofrimento e resiliência: o impacto do abuso sexual na saúde de mulheres vitimadas em Manaus.2007. 198 f. Tese (Doutorado) - Universidade Federal do Espírito Santo, Programa de Pós-Graduação em Psicologia, Vitória, 2007. Disponível em:

http://repositorio.ufes.br/bitstream/10/9104/1/tese_687_.pdf. Acesso em: 20 fev. 2019.

MINAYO, Maria Cecília de Souza; DESLANDES, Suely Ferreira; GOMES, Romeu (org.) Pesquisa social: teoria, método e criatividade. Petrópolis, Rj: Vozes, 1994.

ORLANDI, Eni. Análise do discurso: princípios e procedimentos. Campinas, SP: Pontes, 1999.

@rquivo Brasileiro de Educação, Belo Horizonte, v. 6, n. 14, mai-ago, 2018. 
ORLANDI, Eni. Discurso e texto: formulação e circulação dos sentidos. Campinas, SP: Pontes Editores, 2008.

PÁDUA, Elisabete Matallo Marchesini de. Metodologia da pesquisa: abordagem teórico-prática. 13. ed. Papirus. Campinas, SP.2007.

PAIVA, Eliane Aparecida Faria de. A prevenção primária e secundária do abuso sexual na educação infantil: reflexões no âmbito das políticas públicas. 2015. 250 f. Dissertação (Mestrado) - Universidade Estadual de Campinas, Programa de Pós-Graduação em Educação, Campinas,SP, 2015.

PIRES, Ana L. D.; MIYAZAKI, Maria C. O. S. Maus-tratos contra crianças e adolescentes: revisão da literatura para profissionais da saúde. Arquivo de Ciências da Saúde, jan-mar, 12(1): 42-49, 2005.

ROMERO, Karen Richeter Pereira dos Santos. Crianças vítimas de abuso sexual: aspectos psicológicos da dinâmica familiar.Curitiba: Centro de Apoio Operacional da Promotoria da Criança e Adolescente, 2007.

SEVERINO, Antônio Joaquim, Metodologia do trabalho científico. 23. ed. rev. e atual. São Paulo: Cortez, 2007.

VAGLIATI, Ana Carla; GAGLIOTTO, Giseli M. Formação de Professores e Educação Sexual: O conhecimento psicanalítico na prevenção e identificação da violência e abuso sexual contra crianças e adolescentes na escola. Revista Teias, v. 15, n. 37, 168-177, 2014. 